\title{
Analysing stimuli and barriers, failure and resilience in companies' internationalization: a systematic and bibliometric review
}

Systematic and

bibliometric review

\author{
Rui Martins
}

Faculdade de Ciencias Sociais e Humanas, Universidade da Beira Interior and NECE - Research Unit in Business Sciences, Covilha, Portugal

Luis Farinha

Instituto Politecnico de Castelo Branco and

NECE - Research Unit in Business Sciences, Castelo Branco, Portugal, and

Joao J. Ferreira

Faculdade de Ciencias Sociais e Humanas, Universidade da Beira Interior and NECE - Research Unit in Business Sciences, Covilha, Portugal

\begin{abstract}
Purpose - This study aims to systematize and analyze the internationalization of companies in an attempt to identify the main themes explored in the literature - What does the current state of the art tell us about the stimuli and barriers, failures and resilience in the internationalization of companies is what the authors set out to answer with this research.

Design/methodology/approach - This study offers a systematic review based on the bibliometric mapping techniques of 218 articles collected from the Web of Science database between 1996 and 2021.

Findings - Furthermore, contributing to literature by the logic of stimuli, barriers failure in internationalization companies. The main conclusion is that, from the analysis, the authors can see that the scientific production in this field of knowledge has intensified in recent years, but the centrality and the search density undergo major changes.

Originality/value - The main research contributions enable a better understanding of the involvement of failure and resilience in companies re-internationalization and suggestions for future studies in this field.
\end{abstract}

Keywords Business, Systematic literature review, Internationalization strategy

Paper type Literature review

\section{Introduction}

Internationalization has emerged as an increasingly topical issue, attracting great interest across the scientific community, and therefore, also the higher levels of study that explain

The authors are grateful to the anonymous referees of the journal for their extremely useful suggestions to improve the quality of the article.

Declaration of conflicting interests: The authors declared no potential conflicts of interest with respect to the research, authorship and/or publication of this article.

Funding: The authors received no financial support for the research, authorship and/or publication of this article.
Received 16 July 2021 Revised 26 October 2021 Accepted 14 November 2021 
the exponential rise in publications in recent decades (Morais and Ferreira, 2020; Ipsmiller and Dikova, 2021; Sousa et al., 2021). Furthermore, company internationalization represents a strategic option for their sustainability and gains in economic competitiveness, potentially resulting from this process (Paul et al., 2017).

This research extends beyond analyzing the benefits of internationalization to consider the main themes studied in the literature on company internationalization, analyzing indepth the barriers, failures and incentives to re-internationalization. The state-of-the-art literature does feature high-quality research on internationalization (Eduardsen and Marinova, 2020) and, for example, about SMEs internationalization (Kahiya, 2020; Morais and Ferreira, 2020) or family business internationalization (Debellis et al., 2020; Metsola et al., 2020). Moreover, the diversity of literature generates the need for the systematization of this field's main contributions and discoveries. There is a deficit in the literature in studying the internationalization processes of companies that clarify barriers/obstacles, failures with processes in the re-internationalization and stimuli that lead to new approaches of re-internationalization. Therefore, there is a need to analyze, synthesize and report on the preponderant themes undergoing research and development in companies' internationalization and identify priority areas to develop a knowledge map for company internationalization processes.

The application of a Systematic Literature Review (SLR) approach ensures the production of a framework allowing for deeper analysis of the literature by adopting a transparent scientific process susceptible to replication by other researchers (Denyer and Tranfield, 2009). The benefits of this methodology derive from the scope for synthesizing the research while minimizing bias.

Hence, this study aims to systematize and analyze the literature detailing research on company internationalization over the past 25 years (1996-2021), setting out a systematic review based on the bibliometric mapping techniques of 218 articles collected from the Web of Science, build a framework in VOSviewer that exemplifies the internationalization process model by clusters and an informative map enabling the classification of five clusters.

What does the current state-of-the-art tell us about the stimuli and barriers, failures and resilience in companies' internationalization? To answer this research question provides contributions at both the academic and the business levels to the field of international business, allowing the configuration of a map of knowledge, enabling the design of pathways to internationalization, thus obtaining the key to the (in)success of companies in international markets.

Indeed, even the government bodies responsible for supporting and encouraging such internationalization processes cannot fully support businesses, particularly due to the lack of broad support from other government organizations.

This study offers a systematic review based on the bibliometric mapping techniques of 218 articles collected from the Web of Science database between 1996 and 2021.

Furthermore, this contributes to the literature on the logic of stimuli and barrier failures in internationalization companies. The main conclusion states that, from the analysis, we find that scientific production in this field of knowledge has intensified in recent years even while the centrality and the search density has undergone major changes.

In practical terms, by highlighting the internationalization of companies, this study allows company managers that have not yet expanded into international markets to ascertain which factors to consider for their internationalization processes, especially in terms of the strategies for adoption, the modes of internationalization, entering new markets, the barriers faced and the impact of internationalization on their levels of performance. 


\section{Scope of the review}

Recent decades have seen the study of the internationalization of companies surge in importance and only deepened by the weighting such companies hold in the world panorama (Fernández and Nieto, 2005) in keeping with their capacity to leverage the new opportunities created by globalization (Mathews and Zander, 2007).

Companies initially aim to internationalize to culturally similar countries, representing a cornerstone in the Uppsala model (Johanson and Widersheim-Paul, 1975; Johanson and Vahlne, 1977), as they are closer in terms of psychic distance before these firms then gradually enter new markets that present a greater psychic distance.

The strategy of early internationalization helps to increase competitiveness, facilitating access to new product ideas, innovation and technology, as well as the ability to engage in export activities (Bianchi et al., 2017), and is thus fundamental to ensuring the survival and growth of enterprises.

When companies go international, they can have unavoidable repercussions, culminating in a critical decision, the failure of these companies in international markets (Sedziniauskiene et al., 2019).

The de-internationalization of companies encapsulates the total or partial withdrawal from foreign markets (Welch and Welch, 2009), therefore, leaving or cutting operations in one or more countries and changing how companies enter and engage with these markets (Johanson and Vahlne, 2009). The reasons for companies undertaking de-internationalization of companies include changes in the external environment (Swoboda et al., 2011), decreasing local demand (Welch and Wiedersheim-Paul, 1980), competition (Javalgi and Todd, 2011), resource costs (Boddewyn, 1979), changes and international commitments (Benito and Welch, 1994).

Many companies leave the international scene after such negative experiences that there remains a strong disinterest in any attempt at resuming their international involvement. Furthermore, this group is difficult to motivate even when government internationalization assistance/support schemes (Crick, 2004). However, the de-internationalization of companies does not always represent failure and may emerge as a strategic option (Benito, 2005) and a logically made decision in view of the market assessment, where normally these markets are small and with low exit costs. Exchange rates may also play a role in this process, as emphasized in a study by Crick (2004), where this was a preponderant factor in the international exit of companies that nevertheless maintained an interest in returning to such operations.

Entrepreneurs accumulate limited knowledge about the main export markets and learn from market penetration experiences to improve the capabilities of their companies (Gray and McNaughton, 2010); after an initial step backward, they continue their learning and growth processes, moving from de-internationalization to re-internationalization (Hallbäck and Gabrielsson, 2013).

Re-internationalization involves a period of international business activity and then followed by an interregnum of operations for a certain period until there is again an international re-entry process leading to the successful renewal of international operations (Welch and Welch, 2009). This process incorporates learning, positive behaviors towards reinternationalization and the capacity for resilience in the face of obstacles that were not initially overcome.

Nevertheless, several authors acknowledge other factors that re-internationalization entails, such as entry and exit costs, which may be too low/high and health and financial crises with potentially devastating effects (Ratten, 2020). Firms may also choose to re-enter international markets by assuming new networking relationships (Hadjikhani, 1997), including different resources and capabilities (Javalgi and Todd, 2011), opting for other
Systematic and bibliometric review

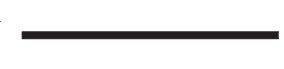


entry costs (Roberts and Tybout, 1997) and diverging from previously established strategies (Jones et al., 2011) in their decisions to re-enter international markets. Some authors also identify other factors that influence and lead to the re-internationalization of companies, such as changes of ownership (Welch and Welch, 2009), the acquisition of additional experience (Benito and Welch, 1994), reductions in trade barriers (Javalgi and Todd, 2011) and improvements in the prevailing market conditions (Crick, 2004; Swoboda et al., 2011).

\section{Methodology}

Planning the review

As Denyer and Tranfield (2009) proposed the SLR used in this study consists of five phases that cover the progress and realization of the SLR. The first phase involves formulating the SLR research questions that ultimately guide and define the subsequent studies and analysis. The research question specified in the introduction section of this study represents the starting point for the SLR and shows the entire data collection and analysis process.

The second phase then proceeds to collect the articles for inclusion in the systematic review; we made recourse to the Web of Science database.

\section{Selection criteria}

The choice of the database stems from the predominance of peer-reviewed journals of high relevance to the topic of internationalization it contains that ensures the accuracy and academic quality of the articles included in the sample (Jones et al., 2011), which underpins confidence in the results presented. The survey took place during June 2021 and deployed the following keywords, "internationali* strategy," "re-international*" and "de-International*" which returned 218 articles then stored in the RIS and CSV formats and coded by Excel (version 2013) and VOSviewer (v1.6.9).

Following this selection phase, we carefully analyzed the records that make up the study with the most relevant information stored to identify the objectives of the respective studies and their methodologies, key findings and contributions. This process involved highlighting the key aspects of each article. The method applied made it possible to cross-check the information obtained with other articles and systematize and thematically categorize them.

The VOSviewer software illustrates, visualizes and builds scientific maps based on the citation data and keywords according to the co-occurrence data and encountering collaborative networks between authors. This software also applies the VOS (visualization of similarities) mapping technique to build maps based on the distance between two items and reflect the relationship's strength. Combining these tools allowed the data coding to identify production indicators (e.g. published articles), produce tables and draft descriptive graphics.

Bibliometric mapping was developed to build a scientific map, most commonly used as co-citation of documents and analysis of co-words, the thematic evolution based on the coword network analysis and clustering is a methodology inspired in Cobo et al. (2011) and the details for the creation of an interesting and informative map it is possible to classify the clusters.

The database study selection and evaluation phase (Phase 3) defined the criteria for validating the inclusion or exclusion of the articles through analyzing the contribution made to the study of the internationalization of companies and considering how the incidence of studies on this subject gained greater acuteness at the beginning of this century.

Data extraction. In this SLR (Phase 4), we have considered only articles and reviews. Thus books, book chapters, reports and conference papers were excluded from the database due to the variability in their review processes (Jones et al., 2011), and only takes into account research produced in the fields of Business, Business Finance Development Studies, 
Economics, Engineering Industrial, International Relations, Management Operations Research Management Science and Social Sciences Interdisciplinary.

EndNote and Mendeley's citation management software served to store the articles before proceeding with reading the abstracts to ensure their relevance to the study. Finally, a more careful analysis of the articles took place and two documents subject to exclusion because is in another language. Thus, the number of articles in the final sample totals 218 , including the empirical studies (quantitative and qualitative), conceptual and/or theoretical articles eligible for review. The final SLR phase formally sets out the results obtained and discusses the findings within the scope of the theme subject to study, thereby identifying the existing gaps and proposing a future research agenda. Figure 1 summarizes the criteria and selection process of the papers that comprise the sample.

\section{Results}

\section{Descriptive data analysis}

This SLR displays a significant increase in citations from the beginning of the century through 2020 (Figure 2). From 1996 until 2021, there are few annual variations in the number of articles, with its peak occurring in 2020 with 32 articles. The article "Emerging multinationals from mid-range economies: The influence of institutions and factor markets," by Hoskisson et al. (2013), was the most cited article, with 374 citations.

\section{Network and cluster analyses}

The network analysis performed in this research applied the VOSviewer software programs, which are complementary bibliometric tools as they serve to undertake bibliometric analysis

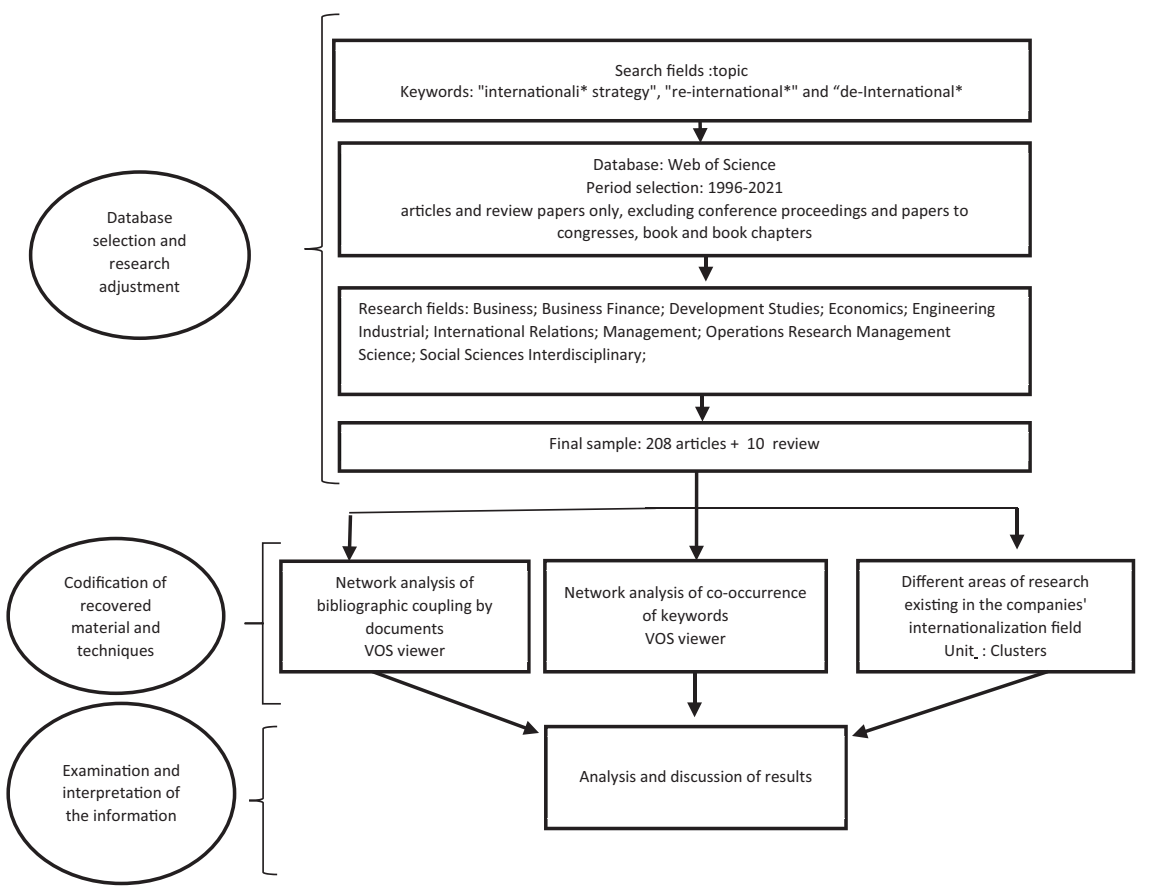

Systematic and

bibliometric review

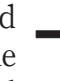


of the data sourced from the Web of Science database, which produces graphic, map-based representations.

Figure 3 displays the analysis of co-occurrence of all keywords summarizes the selection process with eight or more co-occurrence, comprising a final sample of 56 keywords.

The bibliographic coupling of the unit of analysis of documents increasingly serves as the preponderant tool to assess collaboration trends, allowing researchers and leading organizations to be identified (Fonseca et al., 2016). Figure 4 summarizes the selection process of authors with four or more citations, comprising a final sample of 133 articles in 5 clusters.

\section{Thematic analysis}

After completing the content analysis of the articles, we compiled them into the different themes established to categorize the studies and reflecting the different areas of research existing in the companies' internationalization field.

Figure 2.

Evolution of the number of articles and citations by year

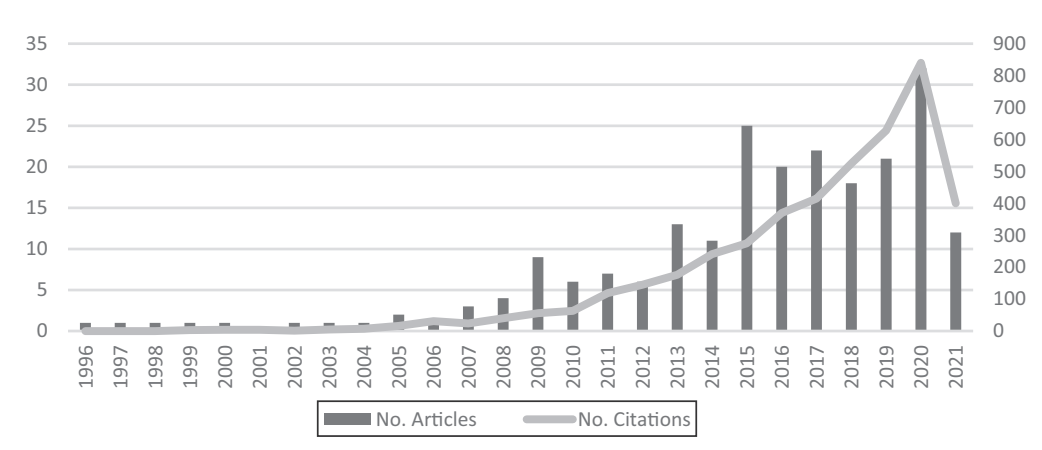

\section{Figure 3.}

Network analysis of co-occurrence of keywords

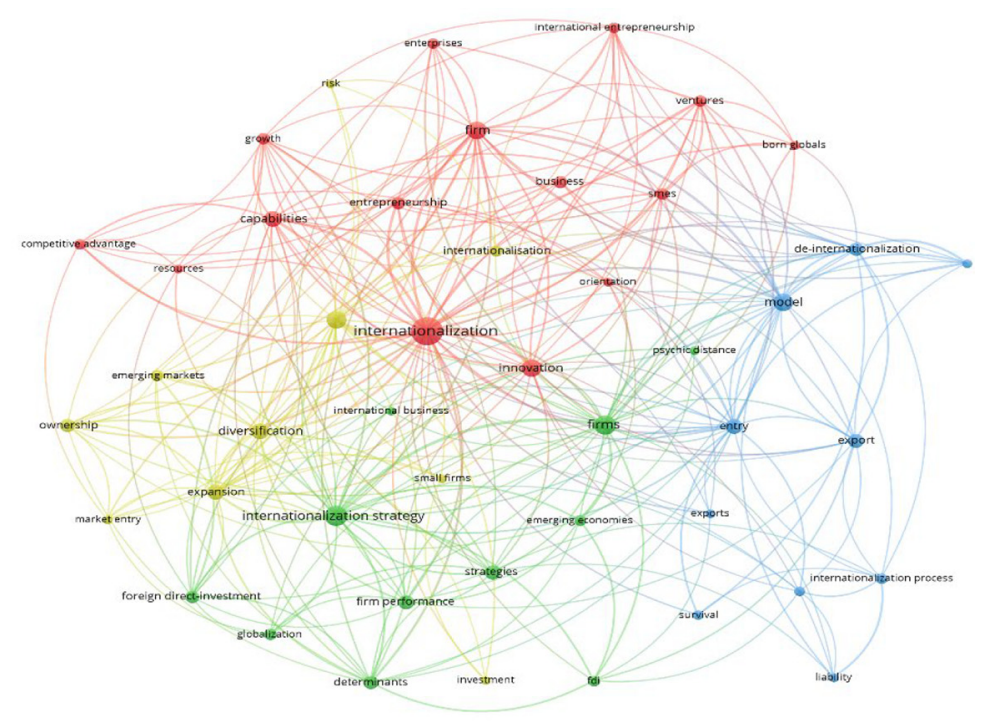




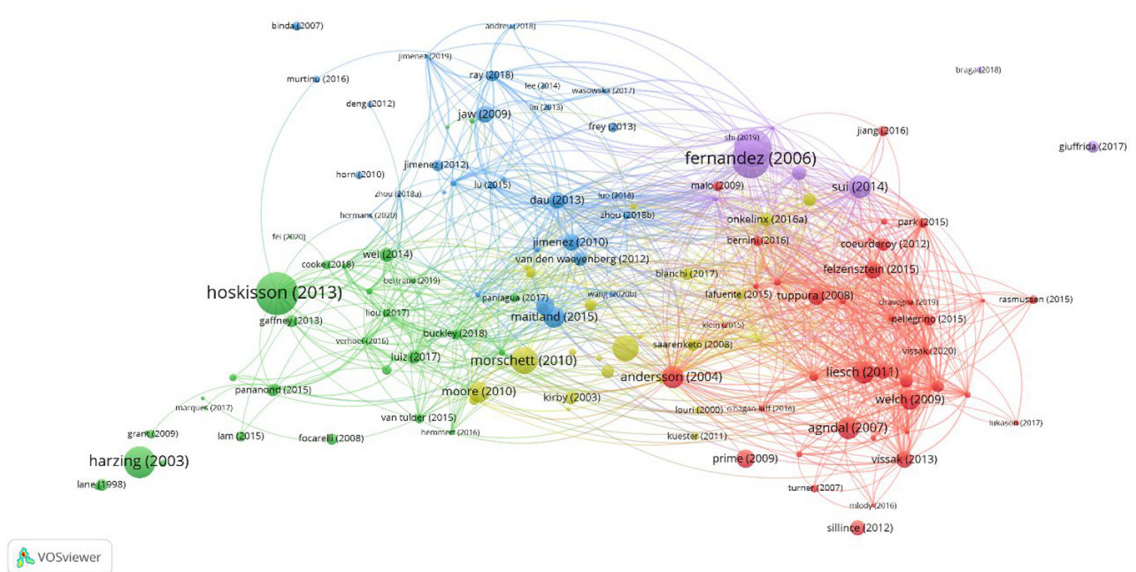

Systematic and bibliometric review

Figure 4. Network analysis of bibliographic coupling by documents

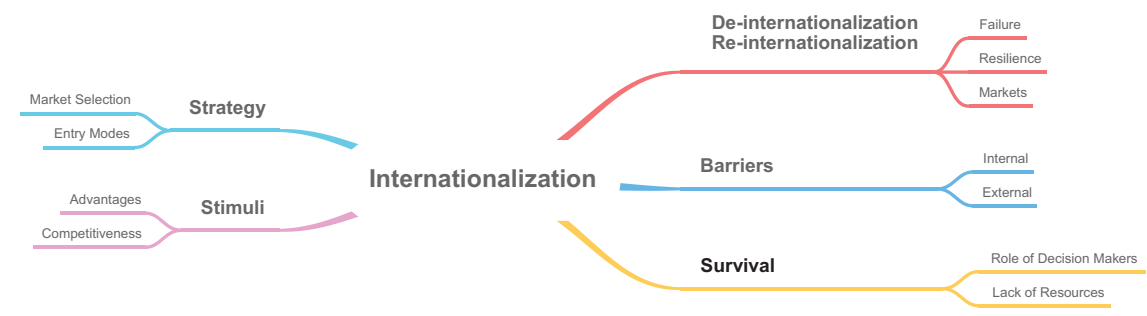

Figure 5. Thematic foci of the studies

Accordingly, the results allow to identify the following five clusters: strategy; Deinternationalization and re-internationalization; barriers; stimuli; survival, as presented in Figure 5 .

Cluster 1 ( $n=32$ articles): strategy

Figure 4 details Cluster 1 in green and brings together the 32 articles (Table 1) that analyze internationalization strategies within the scope of enhancing standards of company performance, through emphasizing the scope of globalization, on occasion targeting emerging markets and economies and thereby seeking to engage in foreign direct investment.

The internationalization strategies began to take on greater importance in the 1990s (Lane, 1998) and with the first study produced by O'Neill in 1996, who studied the hollowing out of the role of the Australian state according to which Grant and Venzin (2009) subsequently emphasized that internationalization strategies need adapting, and to an unprecedented extent, to the positioning of companies.

The research by Alguacil et al. (2017) conveys the differences between exporting companies and those making recourse to foreign direct investment, similar to the study by Wei et al. (2014), through examining the means of entrance of Chinese companies and whether or not they opt for foreign direct investment to enter international markets.

Boehe (2016) warns that with the scarcity of resources, companies need to engage in foreign direct investment to acquire intangible resources in international markets, and with 


\section{RIBS}

\begin{tabular}{|c|c|c|c|}
\hline No & Journals & No. articles & Authors \\
\hline 1 & $\begin{array}{l}\text { International } \\
\text { Business Review }\end{array}$ & 17 & $\begin{array}{l}\text { Eduardsen and Marinova (2020); Niittymies (2020); Ozkan } \\
\text { (2020); Vissak, Francioni and Freeman (2020); Loufrani- } \\
\text { Fedida et al. (2019); Dominguez and Mayrhofer (2017); } \\
\text { Cerrato, Crosato and Depperu (2016); Jiang et al. (2016); } \\
\text { Vissak and Masso (2015); Wei et al. (2014); Gaffney, Kedia } \\
\text { and Clampit (2013); Vissak and Francioni (2013); Jimenez } \\
\text { and Delgado-García (2012); Jiménez (2010); Prime, Obadia } \\
\text { and Vida (2009); Welch and Welch (2009); Tuppura, } \\
\text { Saarenketo, Puumalainen, Jantunen and Kylaheiko (2008) }\end{array}$ \\
\hline 2 & $\begin{array}{l}\text { Journal of } \\
\text { International } \\
\text { Business Studies }\end{array}$ & 8 & $\begin{array}{l}\text { Wang, Gu, Von, Mary and Hirsch (2020); Choquette (2019); } \\
\text { Bernini, Du, Love and James (2016); Maitland and } \\
\text { Sammartino (2015); Sui and Baum (2014), Dau (2013); } \\
\text { Schotter and Beamish (2013); Fernández and Nieto (2006) }\end{array}$ \\
\hline 3 & $\begin{array}{l}\text { Entrepreneurial } \\
\text { Business and } \\
\text { Economics Review }\end{array}$ & 6 & $\begin{array}{l}\text { Wojcik and Ciszewska-Mlinaric (2020); Hadrys-Nowak } \\
\text { (2018); Wąsowska (2017); Mlody (2016); Jaklic and } \\
\text { Karageorgu (2015); Wach (2015) }\end{array}$ \\
\hline 4 & $\begin{array}{l}\text { Journal of Business } \\
\text { Research }\end{array}$ & 6 & $\begin{array}{l}\text { Ciravegna, Kundu, Kuivalainen and Lopez (2019); Cooke, } \\
\text { Wu, Zhou, Zhong and Wang (2018); Crick et al. (2020); Luo } \\
\text { and Zheng (2018); Auletta (2015); Van den Waeyenberg } \\
\text { and Hens (2012) }\end{array}$ \\
\hline 5 & $\begin{array}{l}\text { Multinational } \\
\text { Business Review }\end{array}$ & 6 & $\begin{array}{l}\text { Kaczmarek and Nyuur (2021) Hermans and Borda Reyes } \\
\text { (2020); Kuiken, Wentrup and Schweizer (2020); Aguilera, } \\
\text { Flores and Kim (2015); Pananond (2015); Van Tulder (2015) }\end{array}$ \\
\hline 6 & $\begin{array}{l}\text { Management } \\
\text { International Review }\end{array}$ & 5 & $\begin{array}{l}\text { Buckley (2018); Zhou (2018); Pellegrino and McNaughton } \\
\text { (2015); Richter (2014); Liesch et al. (2011) }\end{array}$ \\
\hline 7 & $\begin{array}{l}\text { Journal of } \\
\text { International } \\
\text { Entrepreneurship }\end{array}$ & 4 & $\begin{array}{l}\text { Cano, Fuentes and Sanchez (2021); Oyson (2020); Rastrollo- } \\
\text { Horrillo and Martin-Armario (2019); Alejandra, Cristina } \\
\text { and Ciravegna (2016); Thurner, Gershman and Roud (2015) }\end{array}$ \\
\hline 8 & $\begin{array}{l}\text { Asian Business and } \\
\text { Management }\end{array}$ & 4 & $\begin{array}{l}\text { Jansson and Soderman (2013); Yiu, Ng and Ma (2013); } \\
\text { Pananond (2012); Horn, Forsans and Cross (2010) }\end{array}$ \\
\hline 9 & Business History & 4 & $\begin{array}{l}\text { Verhoef (2016); Binda and Colli (2011); Strandskov and } \\
\text { Pedersen (2008); Binda and Iversen (2007) }\end{array}$ \\
\hline 10 & International Small & 4 & $\begin{array}{l}\text { Onkelinx et al. (2016); Park, LiPuma and Prange (2015); } \\
\text { Hilmersson (2014); Coeurderoy et al. (2012) }\end{array}$ \\
\hline
\end{tabular}

$3 \quad$ Zhou (2018); Drauz (2013); Deng et al. (2012)

11 Chinese Management

3 Bertrand, Betschinger and Laamanen (2019); Ray et al.

12 Global Strategy

Journal

13 International

Marketing Review

14 Journal of Business and Industrial (2018); Luiz et al., 2017)

$3 \quad$ Magnani and Zucchella (2019); Jensen and Petersen (2014); Freeman, Deligonul and Cavusgil (2013)

3 Calvo and Villarreal (2019); Hanell and Nordman (2019);

Marketing

15 Journal of

International

Management

Table 1.

16 Long Range Planning

Turner and Gardiner (2007)

3 Murtinu and Scalera (2016); Onkelinx, Manolova, Tatiana S. and Edelman (2016); Morschett, Schramm-Klein and Swoboda (2010)

Journals with most

17 Revista de História Shi, Graves and Barbera (2019); Boehe (2016), Grant and Venzin (2009) publications Industrial 
Van (2015) also highlighting how the attitudes of chief executive officers are fundamental to obtaining these commitments.

The Calia and Ferrante (2013) research findings emphasize how company characteristics influence their choice of pattern for internationalization with Marques et al. (2017) reflecting on how companies located in emerging markets strive to enter developed markets in conjunction with a strategy for diversification able to minimize the company's exposure to risk (Luiz et al., 2017).

Bertrand et al. (2019) returned evidence that companies, whenever opting to expand their activities into different markets, opt for less corrupt countries even while Quer et al. (2018) conclude that companies incorporating capital stakes held by the Chinese state display a greater probability for opting to enter markets involving high levels of political risk.

\section{Cluster 2 ( $n=38$ articles): De-internationalization and re-internationalization}

Cluster 2, depicted in red (Figure 4), contains the largest number of studies (Table 1) approaches the development of international entrepreneurial initiatives that cast a particular emphasis on risk and the phenomena surrounding de-internationalization and reinternationalization.

The theme of corporate internationalization gains special relevance when companies try to accelerate and diversify their international expansion strategies, then those that lack these strategies (Wach, 2015) do not survive in international markets (Jiang et al., 2016).

However, increasing levels of uncertainty (Park et al., 2015) can culminate in the deinternationalization of companies (Liesch et al., 2011), not all entrepreneurs are ready for international expansion as the institutional capacities of their companies negatively moderate the relationships in underdeveloped host country institutional environments and in cases of accelerated company internationalization (Vissak et al., 2020).

After their initial setback phase, continuing with their learning and growth processes (Vissak, 2014) closely interlinks exit and re-entry. Firms with a low probability of exit also have a high likelihood of re-entry and vice versa. However, the way firms react to market conditions at the time of exit is important in determining the probability of re-entry, and thus re-entry crucially depends on the strategic logic behind the exit (Bernini et al., 2016).

Entrepreneurs accumulate limited knowledge about their main export markets and learn from the experiences of re-entry and market penetration to improve the capabilities of their companies (Vissak and Francioni, 2020).

Many companies withdraw from international operations, go through an interregnum, and then re-enter the international arena (Welch and Welch, 2009), recognizing the prevailing international opportunities (Dominguez and Mayrhofer, 2017) shaped by the mental images of the entrepreneur collaborating between companies and the foreign market.

Understanding the consequences of de-internationalization processes may contribute to greater awareness around the management of overseas operations, as decision-makers responsible for international expansion should not ignore the ongoing processes, especially due to the sensitive nature of the underlying decisions, such as financial losses, declining exports (Vissak et al., 2018) and company credibility issues (Crick et al., 2004).

Choquette (2019) analyzes the decisions over exiting an international market in accordance with the sunk costs meanwhile incurred, however, some companies opt only for partial de-internationalization as they leave and return to the same markets with some frequency (Bernini et al., 2016).

Cluster 3 ( $n=30$ articles): barriers

The blue-colored Cluster 3 (Figure 4) represents an essential and multi-developed pillar to the architecture of internationalization through an approach that values the resources and 
capacities applied to leverage innovation and in the sense of obtaining competitive advantage and growth (Table 1).

Hendriks et al. (2018) highlight how managers fear that expanding into international markets may bring about financial ruin with the external barriers proving key and inhibiting companies from acting while Yan et al. (2020) demonstrate that the absence of governmental interventions and political changes may bring about a reductive impact.

In turn, the study by Hermans and Borda Reyes (2020) on the Latin-American context stresses the serious shortcomings in effect, including as follows: the capital markets, the low levels of competition and government intervention, which fall far short of that demanded with Jimenez and Delgado-García (2012) also highlighting the greater level of adversity and political risk.

Wang et al. (2020) study the Chinese civil construction sector that, in periods of weak economic growth, explores the global market to generate more robust financial performances even while the criterion of geographic distance represents a determinant factor to these companies (Schotter and Beamish, 2013).

Nevertheless, innovation processes provide excellent opportunities for companies engaging in the "green economy" to be competitive in international markets (Frey et al., 2013) and a core factor in the internationalization of companies, which generates greater competitiveness and profitability (Dau, 2013).

In the research by Ray et al. (2018), Indian family companies shape their international strategy around the pillar of family involvement and company management attributed to the responsibility of nonfamily members (Wąsowska, 2017).

The research findings put forward by Deng et al. (2012), following analysis of the internationalization strategies of private companies with powerful political connections, conclude in favor of their propensity to deploy diversification strategies that contribute towards broader knowledge about markets that facilitates the development of new capacities (Van and Hens, 2012).

\section{Cluster 4 ( $n=24$ articles): stimuli}

This cluster, portrayed in yellow in Figure 4, approaches the increased performance of companies generated by their strategies for expansion, diversification, entrance into new markets and acquiring other companies (Table 1).

The choice over how to enter a market represents a determinant factor to the internationalization strategy (Morschett et al., 2010) as well as holding relevance to expanding beyond the regional framework to improve on the effects of the international expansion (Pisani et al., 2017).

The Bianchi et al. (2017) study establishes due recognition of how the opportunities and the networks shape the relationship between the business orientation and the international performance of companies in emerging markets.

In turn, the research by Strandskov and Pedersen (2008) incorporates the aggressive internationalization strategy through its case study, which made recourse to poorly qualified workers to supply services requiring high levels of labor intensity.

Collaboration-based strategies are susceptible to improving performances (Eisend and Schmidt, 2014) in an approach overlapping with the work carried out by Winch (2014) in the service industry that established concrete connections between the strategic positioning and the network positioning within the scope of internationalization strategies.

The Onkelinx et al. (2016) study demonstrates how internationalization may compensate when the human capital aligns and achieves harmony with the strategy, which emerges as a determinant factor in the research of Jensen and Petersen (2014) that highlights the 
importance of a solid and wide reaching structure for the internationalization of service companies.

\section{Cluster 5 ( $n=9$ articles): survival}

The purple cluster contains the lowest number of publication as detailed in Table 1 with its theme focusing on the survival of companies and in strengthening internationalization processes focused on either exports and/or entering new markets.

The research by Eduardsen and Marinova (2020) highlights the impacts and the implications associated with risk within the framework of companies undergoing internationalization processes, and hence, how companies seeking to engage in such processes encounter internal and external obstacles.

These restrictions faced by companies in terms of their internal barriers interlink with a lack of resources, (Fernández and Nieto, 2005), the scarcity of these same resources for innovation, (Sui and Baum, 2014), for financial resources and for specialist human resources and, as well as for research (Giuffrida et al., 2017), as well as identifying barriers facing managers in terms of logistics for cross-border e-commerce with China.

Nevertheless, Shi et al. (2019) emphasizes how internationalization plays a preponderant role in the strategic processes of companies and generating positive effects on performance (Hilmersson, 2014).

\section{Discussions and future agenda}

The main areas of research on the theme of internationalization of companies, including in the previous clusters, enable the development of a framework (Figure 6) for analyzing companies' internationalization process.

The first strategy cluster essentially covers those studies investigating the following two sub themes: market selection and entry modes, and their interlinked pathways related to internationalization models and company internationalization processes.

Market Selection enables companies to implement and nurture good international business practices to anticipate opportunities for sustainable growth and increase their competitiveness by resorting to international expansion, whether by diversifying the target markets, intensifying their presence in them and/or gaining the trust of new customers.

We also perceive other opportunities for the companies in the entry modes, that feel encouraged and aspire to follow the path of internationalization within a perspective of increased sales, prospects of profits, new opportunities in new markets and strengthening the competitiveness of companies within the framework of which entrepreneurs play relevant in internationalization and attempting to generate competitive advantages for their companies.

The second cluster, entitled "de-internationalization and re-internationalization" encompasses articles that discuss three sub themes, failure, resilience and markets.

The partial or total failure of companies from international markets also identifies interesting pathways that closely interrelate with this cluster, such as companies, internationalization, globalization and models of internationalization and re-internationalization.

Company resilience conveys the capabilities in international markets and the challenge of high competition and the costs of withdrawing from international markets.

The "re-internationalization" analyzes the re-entry of companies into international markets and enables the identification of pathways.

As a theoretical contribution, we conclude here how markets are fundamental to the process of re-internationalization coupled with the learning and entrepreneurial orientations of entrepreneurs and their capacity to offset any shortcomings in the initial process.
Systematic and

bibliometric review

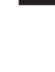




\section{RIBS}

Figure 6.

Knowledge map for the companies internationalization processes

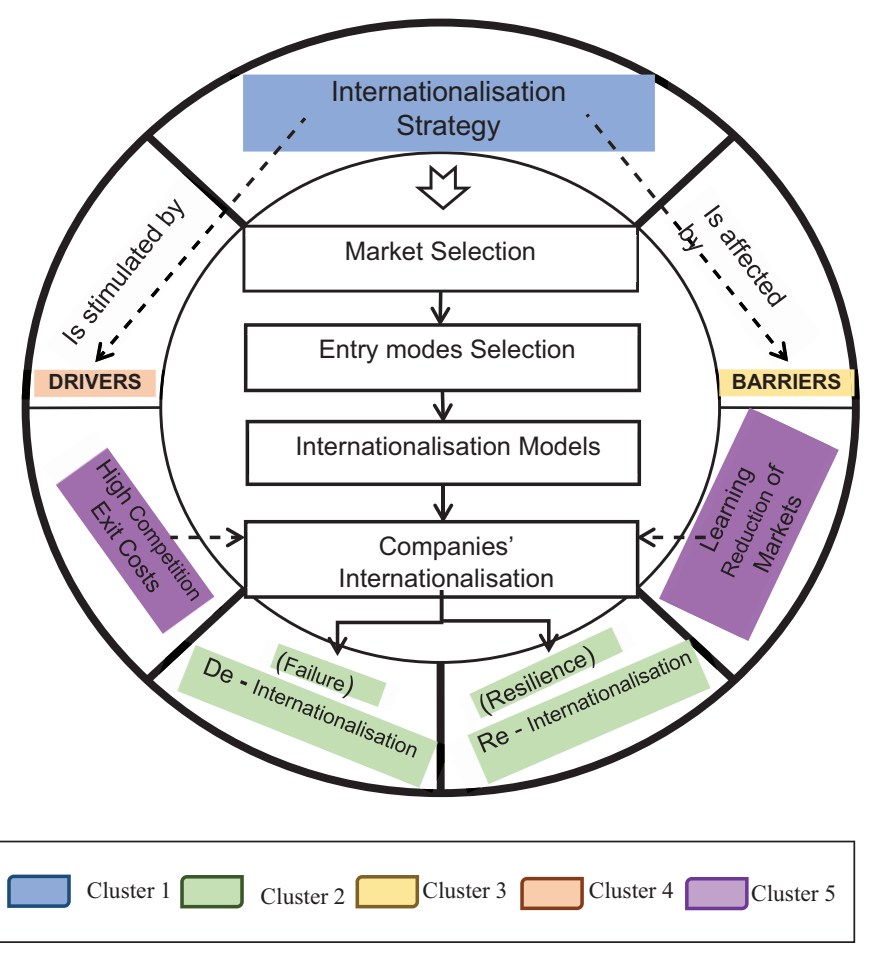

Cluster 3 details the sub themes of internal and external barriers.

The external barriers to the internationalization process and inhibit companies, among which, among others, the absence of government intervention in support of companies, political changes, capital market and low competition stand out.

Companies exposed to foreign exchange risk are conditioned, either on the value of the company in accounting terms, which can suffer large fluctuations, and the respective business profitability can be irreparably compromised, so a management model will be advised to mitigate barriers to allow for improvement and optimizing companies' international transactions to improve the performance and financial results of companies.

Combined with other motivating factors, such as an approach to valuing resources and capabilities to leverage innovation and the feeling of achieving a competitive advantage and growth, it will allow to mitigate and even overcome external barriers.

Cluster 4 is the stimulus that have two sub themes, advantages and competitiveness, that drives companies in an increasingly globalized world to choose the path of internationalization, aiming to increase productivity, economic growth and increase transactions in economies of scale.

Advantages of companies to increase their international presence use expansion strategies, diversification, entry into new markets, acquisition of other companies and resorting to national and/or international networks that allow them to improve products and/or services for international markets, ensuring no competitiveness alone, as adjusting the strategic positioning of companies in the face of fierce competition in international markets. 
Finally, internationalization is also a stimulus for start-ups and spin-offs, as they combine flexibility and adaptability supported by knowledge, which allows them to create new products/services meeting the needs of consumers, contributing to improving competitiveness.

The systematic article review also returned the identification of two thematic subdivisions, the role of decision-makers and lack of resources in the last cluster focuses on the survival of companies in international markets.

The role of decision-makers is preponderant to change management policies, prioritize other more attractive markets, reduce costs and/or develop a new internationalization model.

However, the lack resources can be more drastic if there is a shortage of human and financial resources that are not exceeded and that will cause the company to abandon international markets, focusing only on the domestic market.

Afterward, the decision-makers will carry out a new assessment if they intend to venture again in the international markets or opt for definitive de-internationalization.

Therefore, this SLR represents an attempt to understand the internationalization of companies better and conclude here that strategy is cross-cutting areas to all the preponderant themes of internationalization, reflected both by the development of these areas and by the careful attention given by researchers.

The SLR results identify several sub themes for each cluster of greatest interest, which we shall discuss in the research gaps and potential lines of future research below (Table 2).

The articles collected and systematized enabled the differentiation of two predominant lines of research, which then branch out into the five clusters and sub themes studied above.

The first line of research focuses on the strategy cluster that highlights the barriers to entry, drivers, the human capital of companies, the orientation of the managers/ entrepreneurs and the social relationships they maintain. The levels of innovation and technology in effect are determinant to the internationalization of companies, and hence, the reasons for reduced levels of success in implementing international projects.

The cluster has relevant ramifications for business strategy, identifying gaps while understanding how companies are taking advantage of e-commerce to exploit international markets and how managers/entrepreneurs seek to drive increases in the market shares of their companies.

Future research should also focus on identifying the main challenges companies face when entering constantly evolving international markets. Hence, there is also relevance in studying the extent to which internationalization contributes to company survival, particularly in periods of uncertainty, such as that brought about by the recent COVID-19 health crisis and enabling the undertaking of a comparative study of the rates of company survival and internationalization among countries.

The second research line focuses on re-internationalization and de-internationalization, reasons and incentives for internationalization, and the consequent selection of markets and modes of internationalization for such markets.

Intertwining future lines of research on the re-internationalization and deinternationalization and stimuli clusters, which still require attention from the scientific community and where there remain considerable shortfalls in their reception by business managers, gaps open up, including extending research to other geographical contexts and analyzing how the country of origin shapes the paths of re-internationalization.

Another pathway is the main challenges companies face when re-entering international markets and analyze national and international support provided to companies to catapult them to international markets. 


\begin{tabular}{lll}
\hline Themes & Sub-themes & Research gaps \\
\hline Strategy & Market selection & $\begin{array}{l}\text { Extending research and } \\
\text { analyzing how the country } \\
\text { of origin shapes the paths of } \\
\text { market selection and the } \\
\text { entry modes }\end{array}$
\end{tabular}

Potential RQs for future research

RQ1.1 What are the reasons for the reduced success in implementing international projects, based on triangulation between companies, universities and innovation, using the methodology of case studies RQ1.2 What is the contribution of higher education institutions and technology centers in terms of technology transfer and industrial property, with a view to company approaches to international markets

RQ1.3 How companies use e-commerce to exploit international markets and how they drive their companies to increase market share

Entry modes

De-internationalization Failure and Re-

The literature seems to be internationalization silent on the factors that enable or inhibit RQ1.4 Future research should also focus on identifying the main challenges companies face when entering constantly evolving international markets

RQ2.1 Extend research to other geographical contexts to examine how the commitment on failure country/region of origin affects the deinternationalization paths of enterprises

Resilience

Markets
Studies are required to examine the conditional impact of factors

Extending research to other geographical contexts and analyzing how the country of origin shapes the paths of re-internationalization
RQ 2.2 What are the impacts of the COVID-19 health crisis on the deinternationalization of businesses?

RQ2.3 To explore and better understand the negative impact of experiences on the internationalization of companies RQ2.4 In reinternationalization, do companies follow strategies for re-entering the same
Table 2.

Internationalization future research 


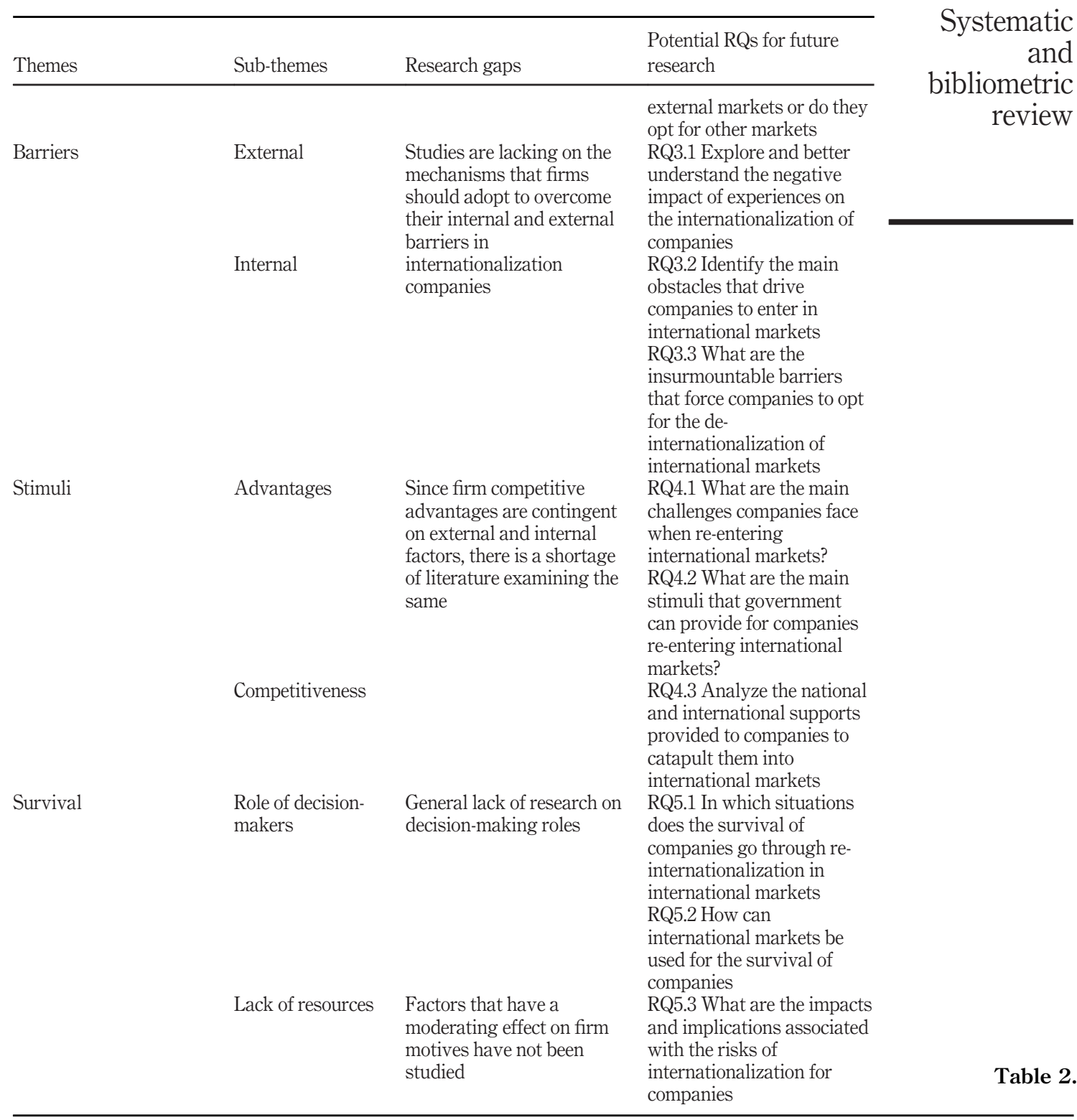

A final but no less important recommendation arises from the main stimuli that the government can give to the companies when re-entering international markets. This would provide for extending the research into other geographical contexts, analyzing how the country/region of origin affects the paths of re-internationalization and de-internationalization of companies and exploring the gap around the decisive role played by the international 
strategy of entrepreneurs/managers in decision-making and alongside the respective implications of their decisions for their companies.

\section{Conclusion}

In this context, our study aims to update the mapping of this area of study, identifying the main current issues related to internationalization, and at the same time, establish a capable framework to serve as a reference and support for researchers, academics and managers.

The SLR methodology has proven a useful tool for advancing the results returned from descriptive literature reviews with its contributions, including synthesizing key literature findings, identifying gaps and establishing a basis for future research. The SLR applied in this study involved a total of 218 articles from the period 1996 to 2021. The analysis and systematization of the articles retrieved made it possible to identify five clusters, which concentrate on the main issues discussed in the internationalization of companies field, among which there is a clear interdependence of issues.

The strategy enables companies to implement and nurture good international business practices to anticipate opportunities for sustainable growth and increase their competitiveness by resorting to international expansion, whether by diversifying their target markets, intensifying their presence in them and/or gaining the trust of new customers.

We also perceive other opportunities for companies that feel encouraged and aspire to follow a path of internationalization within a perspective of increased sales, increased customer portfolios, prospects of improving results/profits, new opportunities in new markets, product expansion and strengthening company competitiveness within the framework of which entrepreneurs/managers play relevant, where not determinant, roles in internationalization and attempting to generate competitive advantages for their companies.

The strategy advocates symmetries between companies and universities, thus improving networks to increasingly improve product/service innovation that fosters both the ability to enter international markets at a later stage and subsequent improvements to performance.

Furthermore, re-internationalization demonstrates how the existence of periods of internationalization of varying duration leads to increases and decreases in company activities that depend essentially on internal and external factors over time.

As a theoretical contribution, we conclude here how markets are fundamental to the process of re-internationalization, coupled with the learning and entrepreneurial orientations of entrepreneurs and their capacity to offset any shortcomings in the initial process.

Should errors escalate and/or other factors, such as entry and exit costs turning out too low/high or the occurrence of financial or health crises, this may cause devastating effects to businesses and lead to their total de-internationalization.

This SLR reveals some natural limitations that researchers in this field should be aware of when interpreting the findings presented here. The SLR only incorporated articles from a single bibliographic database: Web of Science, for the sake of ease of information extraction and reproducibility while covering a wide range of articles and periodicals across the most diverse areas, there are other databases (e.g. EBSCO, Google Scholar and Scopus) that might have served for this purpose. Different theories of internationalization, conceptual structures and other specific theories underpin the work analyzed. The findings and conclusions result from the database constituting the SLR and require interpreting only in that context.

Therefore, this literature review may not be fully comprehensive but provides new insights that complement the knowledge generated by previous studies and help stimulate further research of benefit to the scientific community. 


\section{References}

Alguacil, M., Martí, J. and Orts, V. (2017), "Firm heterogeneity and the market scope of European multinational activity", International Review of Economics and Finance, Vol. 51, pp. 645-659.

Benito, G.R.G. (2005), "Divestment and international business strategy", Journal of Economic Geography, Vol. 5 No. 2, pp. 235-251.

Benito, G.R.G. and Welch, L.S. (1994), "Foreign market servicing: beyond choice of entry mode”, Journal of International Marketing, Vol. 2 No. 2, pp. 7-27.

Bernini, M., Du, J. and Love, J.H. (2016), "Explaining intermittent exporting: exit and conditional reentry in export markets", Journal of International Business Studies, Vol. 47 No. 9, pp. 1058-1076.

Bertrand, O., Betschinger, M.A. and Laamanen, T. (2019), "Effects of subnational regional corruption on growth strategies in emerging economies: evidence from Russian domestic and international M\&A activity”, Global Strategy Journal, Vol. 9 No. 2, pp. 303-332.

Bianchi, C., Glavas, C. and Mathews, S. (2017), "SME international performance in Latin America: the role of entrepreneurial and technological capabilities", Journal of Small Business and Enterprise Development, Vol. 24 No. 1, pp. 176-195.

Boddewyn, J.J. (1979), "Foreign divestment: magnitude and factors", Journal of International Business Studies, Vol. 10 No. 1, pp. 21-27.

Boehe, D.M. (2016), "The internationalization of service firms from emerging economies: an internalization perspective", Long Range Planning, Vol. 49 No. 5, pp. 559-569.

Calia, P. and Ferrante, M.R. (2013), "How do firms combine different internationalization modes? A multivariate probit approach", Review of World Economics, Vol. 149 No. 4.

Choquette, E. (2019), "Import-based market experience and firms' exit from export markets", Journal of International Business Studies, Vol. 50 No. 3, pp. 423-449.

Cobo, M.J., López-Herrera, A.G., Herrera-Viedma, E. and Herrera, F. (2011), "The approach to detecting, quantifying and visualising the evolution of a research field: practical application to the field of fuzzy set theory", Journal of Informetrics, Vol. 5 No. 1, pp. 146-166.

Coeurderoy, R., Cowling, M., Licht, G. and Murray, G. (2012), "Young firm internationalization and survival: Empirical tests on a panel of 'adolescent' new technology-based firms in Germany and the UK", International Small Business Journal, Vol. 30 No. 5, pp. 472-492.

Crick, D. (2004), "U.K. SMEs' decision to discontinue exporting: an exploratory investigation into practices within the clothing industry", Journal of Business Venturing, Vol. 19 No. 4, pp. 561-587.

Crick, J.M., Crick, D. and Chaudhry, S. (2020), "Entrepreneurial marketing decision-making in rapidly internationalising and de-internationalising start-up firms", Journal of Business Research, (October 2017), Vol. 113, pp. 158-167.

Dau, L.A. (2013), "Learning across geographic space: pro-market reforms, multinationalization strategy, and profitability", Journal of International Business Studies, Vol. 44 No. 3, pp. 235-262.

Debellis, F., Rondi, E., Plakoyiannaki, E. and De Massis, A. (2020), "Riding the waves of family firm internationalization: a systematic literature review, integrative framework, and research agenda", Journal of World Business, Vol. 101144.

Deng, X., Tian, Z., Li, J. and Abrar, M. (2012), "The diversification effects of a firm's political connection and its performance implications: evidence from China", Chinese Management Studies, Vol. 6 No. 3, pp. 462-487.

Denyer, D. and Tranfield, D. (2009), Producing a Systematic Review, The SAGE Handbook of Organizational Research Methods.

Dominguez, N. and Mayrhofer, U. (2017), "Internationalization stages of traditional SMEs: increasing, decreasing and re-increasing commitment to foreign markets", International Business Review, Vol. 26 No. 6, pp. 1051-1063. 
Eduardsen, J. and Marinova, S. (2020), "Internationalization and risk: literature review, integrative framework and research agenda", International Business Review, Vol. 29 No. 3, p. 101688.

Eisend, M. and Schmidt, S. (2014), "The influence of knowledge-based resources and business scholars' internationalization strategies on research performance", Research Policy, Vol. 43 No. 1, pp. 48-59.

Fernández, Z. and Nieto, M.J. (2005), "Internationalization strategy of small and medium-sized family businesses: Some influential factors", Family Business Review, Vol. 18 No. 1, pp. 77-89.

Frey, M., Iraldo, F. and Testa, F. (2013), "The determinants of innovation in green supply chains: evidence from an Italian sectoral study", R and D Management, Vol. 43 No. 4, pp. 352-364.

Fonseca, B., de, P.F., Sampaio, R.B., Fonseca, M.V., de, A. and Zicker, F. (2016), “Co-authorship network analysis in health research: method and potential use", Health Research Policy and Systems, Vol. 14 No. 1, pp. 1-10.

Giuffrida, M., Mangiaracina, R., Perego, A. and Tumino, A. (2017), "Cross-border B2C e-commerce to greater China and the role of logistics: a literature review", International Journal of Physical Distribution and Logistics Management, Vol. 47 No. 9, pp. 772-795.

Grant, R.M. and Venzin, M. (2009), "Strategic and organisational challenges of internationalization in financial services”, Long Range Planning, Vol. 42 Nos 5/6, pp. 561-587.

Gray, B.J. and McNaughton, R. (2010), "Knowledge, values and internationalization-introduction to the special edition", Journal of International Entrepreneurship, Vol. 8 No. 2, pp. 115-120.

Hadjikhani, A. (1997), "A note on the criticisms against the internationalization process model", Management International Review, Vol. 37, pp. 43-66, available at: www.jstor.org/stable/ 40228432 (accessed 25 May 2021).

Hallbäck, J. and Gabrielsson, P. (2013), "Entrepreneurial marketing strategies during the growth of international new ventures originating in small and open economies", International Business Review, Vol. 22 No. 6, pp. 1008-1020.

Hendriks, G., Slangen, A.H. and Heugens, P.P. (2018), "How a firm's domestic footprint and domestic environmental uncertainties jointly shape added cultural distances: The roles of resource dependence and headquarters attention Erasmus University Rotterdam Address for reprints: Erasmus University Rotterdam”, Journal of Management Studies, Vol. 55 No. 6, pp. 883-909.

Hermans, M. and Borda Reyes, A. (2020), "A value creation perspective on international business in Latin America: directions for differentiation between emerging market multinationals", Multinational Business Review, Vol. 28 No. 2, pp. 157-175.

Hilmersson, M. (2014), "Small and medium-sized enterprise internationalization strategy and performance in times of market turbulence", International Small Business Journal: Researching Entrepreneurship, Vol. 32 No. 4, pp. 386-400.

Hoskisson, R.E., Wright, M., Filatotchev, I. and Peng, M.W. (2013), "Emerging multinationals from MidRange economies: the influence of institutions and factor markets", Journal of Management Studies, Vol. 50 No. 7, pp. 1295-1321.

Ipsmiller, E. and Dikova, D. (2021), "Internationalization from Central and Eastern Europe: a systematic literature review", Journal of International Management, Vol. 27 No. 4, p. 100862.

Javalgi, R.G. and Todd, P.R. (2011), "Entrepreneurial orientation, management commitment, and human capital: the internationalization of SMEs in India”, Journal of Business Research, Vol. 64 No. 9, pp. 1004-1010.

Jensen, P.D.Ø. and Petersen, B. (2014), "Value creation logics and internationalization of service firms", International Marketing Review, Vol. 31 No. 6, pp. 557-575.

Jiang, G., Kotabe, M., Hamilton, III., R.D. and Smith, S.W. (2016), "Early internationalization and the role of immigration in new venture survival", International Business Review, Vol. 25 No. 6, pp. $1285-1296$. 
Jiménez, A. (2010), "Does political risk affect the scope of the expansion abroad? Evidence from Spanish MNEs", International Business Review, Vol. 19 No. 6, pp. 619-633.

Jiménez, A. and Delgado-García, J.B. (2012), "Proactive management of political risk and corporate performance: The case of Spanish multinational enterprises", International Business Review, Vol. 21 No. 6, pp. 1029-1040.

Johanson, J. and Vahlne, J.E. (1977), “The internationalization process of the firm: a model of knowledge development and increasing foreign market commitments", Journal of International Business Studies, Vol. 8 No. 1, pp. 23-32.

Johanson, J. and Vahlne, J.-E. (2009), "The Uppsala internationalization process model revisited: from liability of foreignness to liability of outsidership", Journal of International Business Studies, Vol. 40 No. 9, pp. 1411-1431.

Johanson, J. and Widersheim-Paul, F. (1975), “The internationalization of the firm: four Swedish cases”, Journal of Management Studies, Vol. 12 No. 3, pp. 305-322.

Jones, M.V., Coviello, N. and Tang, Y.K. (2011), "International entrepreneurship research (1989-2009): a domain ontology and thematic analysis", Journal of Business Venturing, Vol. 26 No. 6, pp. 632-659.

Kahiya, E.T. (2020), "Context in international business: entrepreneurial internationalization from a distant small open economy", International Business Review, Vol. 29 No. 1, p. 101621.

Lane, C. (1998), "European companies between globalization and localization: a comparison of internationalization strategies of British and German MNCs", Economy and Society, Vol. 27 No. 4, pp. 462-485.

Liesch, P.W., Welch, L.S. and Buckley, P.J. (2011), "Risk and uncertainty in internationalization and international entrepreneurship studies review and conceptual development", Management International Review, Vol. 51 No. 6, pp. 851-873.

Loufrani-Fedida, S., Hauch, V. and Elidrissi, D. (2019), "The dynamics of relational competencies in the development of born global firms: a multilevel approach", International Business Review, Vol. 28 No. 2, pp. 222-237.

Luiz, J.., Stringfellow, D. and Jefthas, A. (2017), "Institutional complementarity and substitution as an internationalization strategy:the emergence of an African multinational giant", Journal of Substance Abuse Treatment, Vol. 13 No. 3, pp. 287-288.

Luo, X. and Zheng, Q. (2018), "How firm internationalization is recognized by outsiders: the response of financial analysts", Journal of Business Research, Vol. 90, pp. 87-106.

Marques, J.C., Lupina-Wegener, A. and Schneider, S. (2017), "Internationalization strategies of emerging market banks: challenges and opportunities", Business Horizons, Vol. 60 No. 5, pp. 715-723.

Mathews, J.A. and Zander, I. (2007), "The international entrepreneurial dynamics of accelerated internationalization", Journal of International Business Studies, Vol. 38 No. 3, pp. 387-403.

Metsola, J., Leppäaho, T., Paavilainen-Mäntymäki, E. and Plakoyiannaki, E. (2020), "Process in family business internationalization: the state of the art and ways forward", International Business Review, Vol. 29 No. 2, p. 101665.

Morais, F. and Ferreira, J.J. (2020), "SME internationalization process: key issues and contributions, existing gaps and the future research agenda", European Management Journal, Vol. 38 No. 1, pp. 62-77.

Morschett, D., Schramm-Klein, H. and Swoboda, B. (2010), "Decades of research on market entry modes: What do we really know about external antecedents of entry mode choice?", Journal of International Management, Vol. 16 No. 1, pp. 60-77.

Niittymies, A. (2020), "Heuristic decision-making in firm internationalization: the influence of contextspecific experience”, International Business Review, Vol. 29 No. 6, p. 101752. 
Onkelinx, J., Manolova, T.S. and Edelman, L.F. (2016), "The human factor: investments in employee human capital, productivity, and SME internationalization", Journal of International Management, Vol. 22 No. 4, pp. 351-364.

Park, S., LiPuma, J.A. and Prange, C. (2015), "Venture capitalist and entrepreneur knowledge of new venture internationalization: a review of knowledge components", International Small Business Journal: Researching Entrepreneurship, Vol. 33 No. 8, pp. 901-928.

Paul, J., Parthasarathy, S. and Gupta, P. (2017), "Exporting challenges of SMEs: a review and future research agenda", Journal of World Business, Vol. 52 No. 3, pp. 327-342.

Pisani, N., Caldart, A. and Hopma, J. (2017), "SMEs' formation of minority international joint ventures and level of internationalization: the moderating role of a global versus regional focus", European Management Journal, Vol. 35 No. 3, pp. 414-424.

Quer, D., Claver, E. and Rienda, L. (2018), "The influence of political risk, inertia and imitative behavior on the location", International Journal of Emerging Markets, Vol. 13 No. 3, pp. 518-535.

Ratten, V. (2020), "Coronavirus and international business: an entrepreneurial ecosystem perspective", Thunderbird International Business Review, Vol. 62 No. 5, pp. 1-6.

Ray, S., Mondal, A. and Ramachandran, K. (2018), "How does family involvement affect a firm's internationalization? An investigation of Indian family firm”, Global Strategy Journal, Vol. 8 No. 1.

Roberts, M. and Tybout, J. (1997), "The decision to export in Colombia: an empirical model of entry with sunk costs", The American Economic Review, Vol. 87 No. 4, pp. 545-564.

Schotter, A. and Beamish, P.W. (2013), "The hassle factor: An explanation for managerial location shunning", Journal of International Business Studies, Vol. 44 No. 5, pp. 521-544.

Sedziniauskiene, R., Sekliuckiene, J. and Zucchella, A. (2019), "Networks' impact on the entrepreneurial internationalization: a literature review and research agenda", Management International Review, Vol. 59 No. 5.

Shi, H.X., Graves, C. and Barbera, F. (2019), "Intergenerational succession and internationalisation strategy of family SMEs: evidence from China”, Long Range Planning, Vol. 52 No. 4, p. 1.

Sousa, C.M.P., He, X., Lengler, J. and Tang, L. (2021), "Foreign market re-entry: a review and future research directions", Journal of International Management, Vol. 27 No. 2, p. 100848.

Strandskov, J. and Pedersen, K. (2008), "The foreign expansion of a service company: the case of ISS A/S”, Business History, Vol. 50 No. 1, pp. 40-61.

Sui, S. and Baum, M. (2014), "Internationalization strategy, firm resources and the survival of SMEs in the export market", Journal of International Business Studies, Vol. 45 No. 7 , pp. 821-841.

Swoboda, B., Olejnik, E. and Morschett, D. (2011), "Changes in foreign operation modes: stimuli for increases versus reductions”, International Business Review, Vol. 20 No. 5, pp. 578-590.

Van den Waeyenberg, S. and Hens, L. (2012), "Overcoming institutional distance: expansion to base-ofthe-pyramid markets”, Journal of Business Research, Vol. 65 No. 12, pp. 1692-1699.

Van Tulder, R. (2015), "Getting all motives right: a holistic approach to internationalization motives of companies”, The Multinational Business Review, Vol. 23 No. 1, pp. 36-56.

Vissak, T. (2014), "Nonlinear internationalization in the context of nonlinear economic development: the case of Krenholm group", Transformations in Business and Economics, Vol. 13 No. 2A, pp. 431-447.

Vissak, T. and Francioni, B. (2020), "Re-Internationalization forms and impact factors: four cases", Problemy Zarządzania - Management Issues, Vol. 2020 No. 87, pp. 27-53.

Vissak, T., Francioni, B. and Freeman, S. (2020), "Foreign market entries, exits and re-entries: the role of knowledge, network relationships and decision-making logic", International Business Review, Vol. 29 No. 1. 
Vissak, T., Lukason, O. and Segovia-Vargas, M.-J. (2018), "Interconnecting exporter types with export growth and decline patterns", Review of International Business and Strategy, Vol. 28 No. 1, pp. 61-76.

Wach, K. (2015), "Incremental versus rapid internationalization of firms: results of exploratory investigation from Poland", Entrepreneurial Business and Economics Review, Vol. 3 No. 4, pp. 37-48.

Wang, Y., Hong, A., Li, X. and Gao, J. (2020), "Marketing innovations during a global crisis: a study of China firms' response to Covid-19", Journal of Business Research, Vol. 116, pp. 214-220.

Wassowska, A. (2017), "Internationalization of family firms: the role of ownership structure and composition of top management team", Entrepreneurial Business and Economics Review, Vol. 5 No. 1, pp. 169-185.

Wei, Y., Zheng, N., Liu, X. and Lu, J. (2014), "Expanding to outward foreign direct investment or not? A multi-dimensional analysis of entry mode transformation of Chinese private exporting firms", International Business Review, Vol. 23 No. 2, pp. 356-370.

Welch, C.L. and Welch, L.S. (2009), "Re-internationalization: exploration and conceptualisation", International Business Review, Vol. 18 No. 6, pp. 567-577.

Welch, L.S. and Wiedersheim-Paul, F. (1980), "Initial exports-a marketing failure?", Journal of Management Studies, Vol. 17 No. 3, pp. 333-344.

Winch, G. (2014), "Strategic business and network positioning for internationalization", The Service Industries Journal, Vol. 34 No. 8, pp. 715-728.

Yan, C., Yanghao, Z. and Bhatti, M.H. (2020), "The staged government intervention, situational characteristics and innovation: evidence from China", Human Systems Management, Vol. 39 No. 2, pp. 293-308.

\section{Further reading}

O’Neill, P.M. (1996), "In what sense a region's problem? The place of redistribution in Australia's internationalization strategy", Regional Studies, Vol. 30 No. 4, pp. 401-411.

\section{Corresponding author}

Joao J. Ferreira can be contacted at: jjmf@ubi.pt

For instructions on how to order reprints of this article, please visit our website: 